\section{White-tailed Deer Browsing and Rubbing Preferences for Trees and Shrubs That Produce Nontimber Forest Products}

\author{
Scott E. Hygnstrom ${ }^{1,5}$, Peter D. Skelton ${ }^{2}$, Scott J. Josiah ${ }^{1}$, \\ Jason M. Gilsdorf ${ }^{1}$, Dallas R. Virchow ${ }^{1}$, James A. Brandle ${ }^{1}$, \\ Anil K. Jayaprakash ${ }^{3}$, Kent M. Eskridge ${ }^{3}$, \\ and Kurt C. VerCauteren ${ }^{4}$
}

ADDITIONAL INDEX wORDs. agroforestry, browse, fruit, nuts, Odocoileus virginianus, rub damage, specialty woods, wildlife, woody ornamentals

SUMMARY. Nontimber forest products (food, herbal medicinals, and woody floral and handicraft products) produced in forest, agroforestry, and horticultural systems can be important sources of income to landowners. White-tailed deer (Odocoileus virginianus) can reduce the quality, quantity, and profitability of forest products by browsing twigs and rubbing stems, resulting in direct and indirect losses to production enterprises. We evaluated deer damage (frequency and intensity of browsing and rubbing) sustained by 26 species of trees and shrubs, the relationships among morphological features of trees and shrubs to damage levels, and the economic impacts of deer damage on the production of nontimber forest products. Levels of browsing were high (frequency $>\mathbf{9 3 \%}$ and intensity $>50 \%$ ) in most species of trees and shrubs, with the highest intensity $(>60 \%)$ occurring in chinese chestnut (Castanea mollisima) and dogwood (Cornus spp.), and the lowest $(<\mathbf{2 0 \%})$ in ginkgo (Ginkgo biloba), curly willow (Salix matsudana), 'Scarlet Curls' curly willow, smooth sumac (Rbus glabra), and pussy willow (Salix caprea). Species of trees or shrubs with one or a few stout stems unprotected by dense branching [e.g., american elderberry (Sambucus canadensis), smooth sumac, and curly willow] sustained the most damage by rubbing. Trees and shrubs with many small diameter stems or with dense tangled branching [e.g. redozier dogwood (Cornus sericea), forsythia (Forsytbia suspensa), 'Flame' willow (Salix alba), and 'Streamco' basket willow (Salix purpurea)] were damaged the least by rubbing. Annual economic costs of deer damage to producers of nontimber forest products can range from $\$ 26 /$ acre for pussy willow to $\$ 1595 /$ acre for curly willow.

$\mathrm{N}$ ontimber forest products derived from trees, shrubs, or herbaceous plants include fruits and nuts, herbal medicinals, handicrafts, and specialty woods.

This study was supported by the University of Nebraska Integrated Pest Management-Vertebrates Program.

We thank Jeanine Lackey and Jeremy Hiller for assisting with the field aspects of the project. Seth Korte and Stephen Vantassel provided helpful reviews of the manuscript.

Any opinions, findings, conclusions, or recommendations expressed in this publication are those of the authors and do not necessarily reflect views of the U.S. Department of Agriculture.

${ }^{1}$ School of Natural Resources, University of Nebraska, Lincoln, NE 68583-0974

${ }^{2}$ College of Agriculture and Home Economics, New Mexico State University, Las Cruces, NM 880038001

${ }^{3}$ Department of Statistics, University of Nebraska, Lincoln, NE 68583-0963

${ }^{4}$ United States Department of Agriculture-Wildlife Services-National Wildlife Research Center, Fort Collins, CO 80521

${ }^{5}$ Corresponding author. E-mail: shygnstroml@unl.edu.
Markets for these commercial products may range from local and small to regional niches to large and international. Specialty fruit markets on the Canadian prairies vary in size from less than $1000 \mathrm{lb}$ of pin cherry (Prunus pennsylvanica) to 40,000 lb of choke cherry ( $P$. virginiana) (Solutions 2000+ Management Consultants, 1994). About 1 million pounds of saskatoons (Amelanchier alnifolia) are sold annually in Canada, either fresh or for processing (R. St-Pierre, unpublished data). The market for specialty fruits in the upper midwestern United States was about $\$ 220,000$ / year (Weeder-Einspahr, 2001).

The wholesale market for fresh woody florals was about $\$ 8$ million, exclusive of Pacific coast states in 2000 (Lambe, 2001). Additional woody floral markets exist for decorative woody florals, such as curly willow, pussy willow, and redozier dogwood cultivars Colorado, Bailey, Cardinal, and Yellow-twig. The stems are produced by retail florists for personal use, purchased from local producers, ordered by larger retail florists directly from producers, or sold by large producers that also serve as wholesalers to retail florists and other wholesalers.

The U.S. market for nontimber forest products, including handicrafts such as diamond willow (Salix eriocephala) and 'Streamco' basket willow, was projected to be about $\$ 600$ million in 1996 (U.S. Bureau of the Census, 1993). Over $\$ 3$ billion in herbal medications were sold in the United States, Canada, France, Germany, and the United Kingdom in 1992, some of which can be derived from trees and shrubs that grow in agroforestry systems (Mater, 1996). Exports of american ginseng (Panax quinquefolius) from the United States to Asia ranged from $\$ 22$ million in 1993 to $\$ 32$ million in 1996 (Chamberlain, 2001).

Financial returns from the production of nontimber forest crops can be substantial. Robles-Diaz-de-Leon and Kangas (1997) reported annual gross returns of $\$ 24,282 /$ acre from nontimber forest products produced in riparian zones. Gross annual returns approached $\$ 13,590 /$ acre from nontimber forest products produced in a riparian buffer in Indiana (Miller et al., 1994). Josiah et al. (2004b) reported net financial returns of up to $\$ 17.46 /$ plant per year for woody floral stems produced from 'Scarlet Curls' curly willow.

\begin{tabular}{llll}
\hline $\begin{array}{l}\text { Units } \\
\text { To convert U.S. to SI, } \\
\text { multiply by }\end{array}$ & U.S. unit & SI unit & $\begin{array}{l}\text { To convert SI to U.S., } \\
\text { multiply by }\end{array}$ \\
\hline 0.4047 & acre(s) & $\mathrm{ha}$ & 2.4711 \\
0.3048 & $\mathrm{ft}$ & $\mathrm{m}$ & 3.2808 \\
2.54 & inch(es) & $\mathrm{cm}$ & 0.3937 \\
25.4 & inch(es) & $\mathrm{mm}$ & 0.0394 \\
0.4536 & $\mathrm{lb}$ & $\mathrm{kg}$ & 2.2046 \\
2.5900 & mile & $\mathrm{km}^{2}$ & 0.3861
\end{tabular}


Woody species that produce specialty products can be integrated into agroforestry configurations such as windbreaks, living snow fences, alley cropping arrangements, or riparian forest buffers to improve profitability and sustainability of agricultural systems (Josiah et al., 2004a, 2004b; Miller et al., 1994). Plantings conserve and protect natural resources and generate income through the production of specialty products.

White-tailed deer can reduce the quality, quantity, and profitability of nontimber forest products by browsing twigs and rubbing stems. Heavily browsed woody floral stems are difficult to market because of the emphasis on product quality and appearance in floral markets, resulting in direct economic losses. Browsing can occur year-round and is especially destructive during the winter when alternative foods are less available (Conover, 1984, 1987). Male white-tailed deer also rub the stems of trees and shrubs during autumn to remove velvet from their antlers and to communicate with other deer (Kyle and Marchington, 1977). Rubbing can disrupt the cambium around the circumference of stems, resulting in reduced vigor and often death of trees or shrubs.

To reduce damage by deer and mitigate economic losses, producers often implement lethal and nonlethal techniques to control damage. Regulated hunting and sharpshooting is not always supported by the public and may only be applicable in rural areas due to concerns for human safety and urban ordinances (Jones and Witham, 1995; Kilpatrick et al., 1997; Kuser, 1995; Mayer et al., 1995). Nonlethal techniques are often difficult to apply, expensive to implement, and may only provide temporary relief. Fences, repellents, and frightening devices often provide varying degrees of success in reducing crop damage (Craven and Hygnstrom, 1994). The use of species of trees and shrubs that are less preferred or avoided by deer could make an area less attractive to deer and reduce damage due to browsing and rubbing. Several studies have been conducted on browsing preferences of deer in natural vegetation (Koerth and Stuth, 1991; Nixon et al., 1970; Strole and Anderson, 1992). Relatively few studies, however, have addressed the preferences of white-tailed deer regarding nontimber forest products for browsing and rubbing.

Our objectives were to determine the varying levels of deer damage (browsing and rubbing) sustained by 26 species of trees and shrubs; to relate morphological features of trees and shrubs to damage levels; and to evaluate the economic impacts of deer damage on the production of nontimber forest products.

\section{Materials and methods}

STUdy AREA. We conducted the study in east-central Nebraska at the University of Nebraska Agricultural Research and Development Center [lat. $41^{\circ} 29^{\prime} \mathrm{N}$, long. $96^{\circ} 30^{\prime} \mathrm{W}, 354$ $\mathrm{m}$ elevation, U.S. Department of Agriculture (USDA) Hardiness Zone $4 \mathrm{~b}]$. The facility included 552 acres of cropland and 88 acres of windbreaks, silvopastoral plantings, plantations of several hardwood and softwood tree species [hackberry (Celtis occidentalis), ponderosa pine (Pinus ponderosa), silver maple (Acer saccharinum), and american hazelnut (Corylus americana)], and native bottomland forest (Fig. 1). Predominant tree species

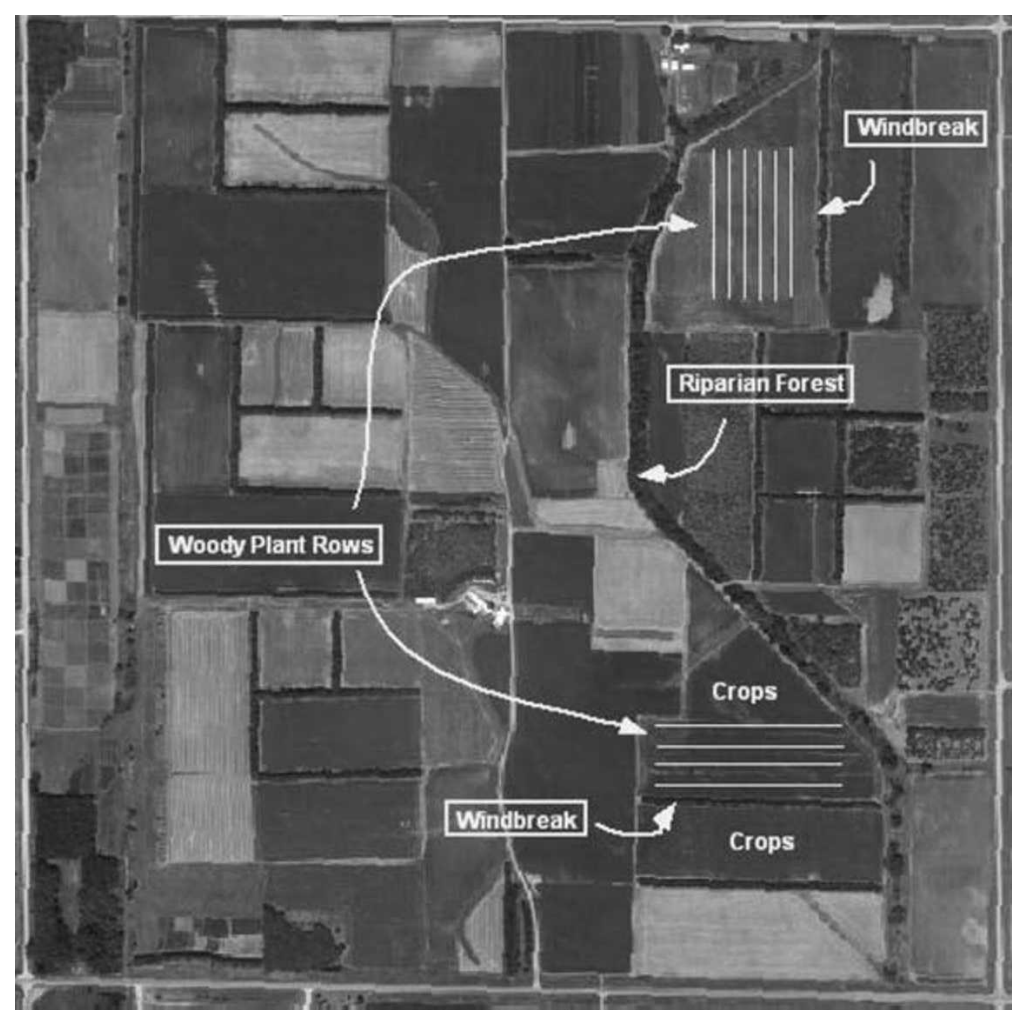

Fig. 1. Nontimber forest product plantings [ 40 acres ( $16.2 \mathrm{ha})]$ at the University of Nebraska Agricultural Research and Development Center Agroforestry facility in southeastern Nebraska, Mar. 2001. included austrian pine (Pinus nigra), eastern cottonwood (Populus deltoides), eastern red cedar (Juniperus virginiana), siberian elm (Ulmus pumila), green ash (Fraxinus pennsylvanica), and boxelder (Acer negundo). Predominant crops included corn (Zea mays), soybean (Glycine max), wheat (Triticum aestivum), and mixed-grass pasture. Annual precipitation totaled 31.2 inches during 1999 and 23.6 inches during 2000 . The normal 30year average annual precipitation is 27.8 inches. The agroforestry complex was occupied by about 48 white-tailed deer per square mile during the study (J. Hoffman, Nebraska Game and Parks Commission, personal communication). No efforts were made to exclude, repel, frighten, or remove deer from the study area.

EXPERIMENTAL DESIGN. To develop realistic production information for nontimber forest products in agroforestry systems, we installed a 40 -acre area for alley cropping research and demonstration in May 1999. The area included 8 and 18 species of trees and shrubs, respectively, that produced commercially valuable nontimber forest products 
(Table 1). Woody plants were purchased from wholesale nurseries in Minnesota, Iowa, Missouri, and Montana. We planted 2- to 3 - $\mathrm{ft}$-tall nursery stock in rows spaced $60 \mathrm{ft}$ apart in two agricultural fields $\approx 2640$ $\mathrm{ft}$ apart, separated by a large hackberry plantation and woody riparian corridor. Corn, soybeans, and wheat were produced in rotation between the shrub and tree rows. Trees were spaced $10 \mathrm{ft}$ apart and shrubs were spaced $5 \mathrm{ft}$ apart within the rows. All rows were $10 \mathrm{ft}$ wide. Blocks of five woody plants per plot (planted adjacent to each other within the row) were repeated 10 times (totaling 50 plants per species or cultivar) in a randomized complete split-block design, where the whole-plot factor was plant type (shrubs or trees) and the split-plot factor was species nested within plant type. Replicates were randomly distributed in the rows (five replicates in each field), but were blocked with respect to adjacent windbreaks. Weeds near trees and shrubs were managed by cutting and with herbicides (glyphosate; Roundup ${ }^{\circledR}$; Monsanto, St. Louis). No sup- plemental irrigation was provided. Fertilizer was not applied directly to woody plants; however, they likely benefited from manure and commercial fertilizers that were applied annually to adjacent row crops.

DAMAge MEASUREMENTS. We evaluated the level of preference by deer for the various species of trees and shrubs by measuring the frequency and intensity of browsing and rubbing in Mar. 2001, after 1 year of growth. Each plant was observed in the field to determine if it had been browsed or rubbed by deer. If a tree or shrub was browsed, we counted the number of twigs that were browsed or unbrowsed. For shrub species that produced flowering or ornamental stems (Table 1), we clipped each shrub at ground level, bundled the stems by plant and moved the bundles to a heated processing area. We randomly collected a $25 \%$ sample of stems from each of these plants and counted the number of twigs per stem that were browsed or unbrowsed. For species or cultivars that produced fruits, nuts, fruiting stems, or medicinal products (Table
1), we counted the total number of stems and the total number of browsed or unbrowsed twigs per stem in the field. Due to the large number of stems and twigs associated with 'Scarlet Curls' curly willow, we collected a random sample of 100 twigs per plant and determined the number that were browsed or unbrowsed. We defined the frequency of browsing as the percentage of plants of a species available that were browsed by deer and the intensity of browsing as the percentage of twigs of a species available that were browsed by deer. If a tree or shrub was rubbed, we estimated the percentage of the circumference of the stem that was rubbed at the mean height of the rub on the stem in the field. We only measured rubs of trees and shrubs that had single stems or that were large enough to be rubbed (minimum of $0.35 \mathrm{~mm}$ diameter). We defined the frequency of rubbing as the percentage of stems available that were rubbed by deer and the intensity of rubbing as the percentage of the circumference of stems available that were rubbed by deer.

Table 1. Woody plant species planted in a 40-acre (16.2 ha) alley cropping system in southeastern Nebraska in Mar. 2001.

\begin{tabular}{|c|c|c|c|}
\hline Woody plant species & Scientific name & Growth form & Product \\
\hline American elderberry & Sambucus canadensis & Multistemmed & Fruit \\
\hline Choke cherry & Prunus virginiana & Multistemmed & Fruit \\
\hline Sand cherry & Prunus pumila & Multistemmed & Fruit \\
\hline 'Blood-twig' dogwood & Cornus sanguinea & Multistemmed & Ornamental stem \\
\hline 'Colorado' redozier dogwood & C. sericea 'Colorado' & Multistemmed & Ornamental stem \\
\hline 'Yellow-twig' redozier dogwood & C. sericea 'Yellow-twig' & Multistemmed & Ornamental stem \\
\hline Forsythia & Forsythia suspensa & Multistemmed & Flowering stem \\
\hline Smooth sumac & Rhus glabra & Multistemmed & Fruit \\
\hline Pussy willow & Salix caprea & Multistemmed & Flowering stem \\
\hline Winterberry holly & Ilex verticillata & Multistemmed & Fruiting stem \\
\hline Witch-hazel & Hamamelis virginiana & Multistemmed & Flowering stem \\
\hline \multicolumn{4}{|l|}{ Trees } \\
\hline Black cherry & Prunus serotina & Single stemmed & Fruit \\
\hline Butternut & Juglans cinerea & Single stemmed & Nut \\
\hline Black walnut & Juglans nigra & Single stemmed & Nut \\
\hline 'Peach' chinese chestnut & Castanea mollissima 'Peach' & Single stemmed & Nut \\
\hline 'Qing' chinese chestnut & C. mollissima 'Qing' & Single stemmed & Nut \\
\hline Ginkgo & Ginkgo biloba & Single stemmed & Medicinal \\
\hline Common persimmon & Diospyros virginiana & Single stemmed & Fruit \\
\hline Northern red oak & Quercus rubra & Single stemmed & Stem \\
\hline
\end{tabular}


We measured the height and width of each tree and shrub using a 3 -m telescoping pole. The stem diameter of each tree was measured at the mean height of the rub for that species or cultivar using a digital caliper. Three of the species of shrubs (american elderberry, curly willow, and 'Scarlet Curls' curly willow) were measured in the same way as trees because of their initial tree-like growth form.

Data analysis. We entered all data into an Excel spreadsheet (Microsoft, Redmond, WA) and sorted by site, species, plot, and block and transferred the data to SAS (version 8; SAS Institute, Cary, NC). We analyzed data from the two fields using an analysis of variance (ANOVA) in a split-plot design, which allowed us to test for interactions among field $x$ plant and field $x$ species $\times$ plant. We generated leastsquare means using a mixed model analysis to test for main effects, interactions, and contrasts. We generated frequency distributions for height, width, stem diameter, percentage of plants browsed and rubbed, and percentage of twigs browsed. We conducted an ANOVA with number of trees and shrubs browsed, circumference rubbed, percentage rubbed, growth form, height, width, and stem diameter as dependent variables, and field, plant, species, and their interactions as independent variables. In addition, we used contrasts to evaluate the effects of single versus multiple stems and dogwood versus willow on frequency and intensity of browsing.

To assess the financial impacts of deer damage, we recorded numbers of stems rendered unmarketable by deer browsing or rubbing while harvesting and processing selected woody florals in Feb. 2001 and Dec. 2001. Not all damage from browsing results in unmarketable stems. Stems browsed near the stem tip, or browsed side spurs were counted as salable, but browsing that created a blunt, relatively wide visible end were rejected as unsalable. We calculated the gross financial losses incurred from deer browsing by species of shrub using the wholesale price and production, processing, and marketing data derived from actual production and sales in 2001 and 2002 (Josiah et al., 2004b).

\section{Results}

The height and width of the plants varied by species $(P=0.0001$ and $P<0.05$, respectively), with curly willow being the tallest shrub $($ mean $=$ $2.6 \mathrm{~m}$ ) and sand cherry (Prunus pumila) being the shortest (mean $=0.4$ $\mathrm{m})$. Black cherry (Prunus serotina) was the tallest tree $($ mean $=2.0 \mathrm{~m})$ and ginkgo was the shortest $[$ mean = $0.3 \mathrm{~m}$ (Table 2)]. Considerable field $\times$ plant type interactions and field $x$ species $\times$ plant type interactions occurred $(P<0.05$ and $P<0.05)$, indicating that trees and shrubs were taller and wider in the north field than in the south field.

Browsing. The percentage of plants browsed by deer (frequency of browsing) differed among the species of trees and shrubs $(P<0.05)$. The mean frequency of browsing across all species of trees was $89 \%$ and was least for ginkgo (40\%) and $>88 \%$ for all other species (Table 2 ). The mean frequency of browsing across all species of shrubs was $98 \%$ and was least for smooth sumac $(80 \%)$ and $>93 \%$ for all other species. Dogwood species were browsed 19\% more than all willow species combined $(P<0.0001)$. Trees and shrubs with single stems were browsed $4 \%$ more than shrubs with multiple stems $(P<0.0078)$. The frequency of browsing on shrubs was two times greater than on trees. A considerable field $x$ plant interaction $(P=0.003)$ and field $\times$ species $\times$ plant interaction occurred $(P<0.05)$, indicating that deer pressure was higher in the north than the south field. Morphological characteristics explained relatively little variance in the frequency of browsing, with height and width each contributing $3 \%$ of the explained variance.

The percentage of twigs browsed by deer (intensity of browsing) differed among the species of trees and shrubs $(P<0.0001)$. The mean intensity of browsing across all species of trees was $52 \%$ and was greatest in chinese chestnut ('Peach' $=76 \%$, 'Qing' $=72 \%$ ), black walnut (Juglans nigra) (58\%), black cherry (57\%), and northern red oak (Quercus rubra) $(54 \%)$, and was least in ginkgo (12\%) (Table 2). The mean intensity of browsing across all species of shrubs was $42 \%$ and was greatest in 'Yellowtwig' redozier dogwood (59\%), witch-hazel (Hamamelis virginiana)
(58\%), 'Blood-twig' dogwood (Cornus sanguinea) (55\%), 'Colorado' redozier dogwood $(55 \%)$, 'Flame' willow $(55 \%)$, choke cherry $(54 \%)$, sand cherry (52\%), and 'Bailey' redozier dogwood $(51 \%)$, and was least in curly willow (11\%), smooth sumac (14\%), 'Scarlet Curls' curly willow (14\%), and pussy willow (20\%). We found no significant differences in the percentage of twigs browsed in dogwood versus willow species combined $(P=0.5232)$. The intensity of browsing on trees and shrubs with single stems was $17 \%$ more than shrubs with multiple stems. However, the twigs of dogwood and willow species combined were browsed $20 \%$ more than trees with single stems $(P=0.0001)$. The species $\times$ plant interaction was significant $(P=0.0001)$. Morphological characteristics explained relatively little variance in the intensity of browsing, with tree and shrub height and width contributing $3 \%$ and $1 \%$, respectively.

RubBING. The percentage of stems rubbed by male deer (frequency of rubbing) differed among the species of trees and shrubs $(P<0.05)$. The mean frequency of rubbing across all species of trees was $17 \%$ and was greatest in black cherry (56\%), followed by persimmon (Diospyros virginiana) (24\%), chinese chestnut ('Qing' $=20 \%$, 'Peach' = 18\%), and butternut (Juglans cinerea) (19\%) (Table 2). All other species of trees were rubbed at a frequency $<11 \%$. The mean frequency of rubbing across all species of shrubs was also $17 \%$ and was greatest in smooth sumac $(96 \%)$, curly willow $(84 \%)$, american elderberry (55\%), and choke cherry $(28 \%)$. All other species of shrubs were rubbed at a frequency $<16 \%$. The stems of willow species were rubbed $19 \%$ more than the stems of dogwood species combined. Trees and shrubs with single stems were rubbed $4 \%$ more than shrubs with multiple stems. Morphological characteristics of the trees and shrubs contributed little to the explained variance in frequency of rubbing, with tree and shrub height, width, and stem diameter explaining 18\%, $1 \%$, and $8 \%$, respectively.

The percentage of the circumference of stems rubbed by male deer (intensity of rubbing) differed among the species of trees and shrubs $(P<$ $0.05)$. The mean intensity of rubbing 
Table 2. Morphological features and incidence of deer damage on tree and shrub species planted in a 40-acre (16.2 ha) alley cropping system in southeastern Nebraska in Mar. 2001.

\begin{tabular}{|c|c|c|c|c|c|c|c|}
\hline \multirow[b]{2}{*}{ Species } & \multirow[b]{2}{*}{$\begin{array}{c}\text { Plant ht } \\
{[\text { mean } \pm \text { SE }(\mathrm{m})]^{\mathrm{y}}}\end{array}$} & \multirow[b]{2}{*}{$\begin{array}{c}\text { Plant width } \\
{[\text { mean } \pm \mathrm{SE}(\mathrm{cm})]^{\mathrm{x}}}\end{array}$} & \multirow[b]{2}{*}{$\begin{array}{c}\text { Stem diameter }{ }^{\mathrm{w}} \\
{[\mathrm{mean} \pm \mathrm{SE}(\mathrm{mm})]^{\mathrm{v}}}\end{array}$} & \multicolumn{2}{|c|}{ Browsing } & \multicolumn{2}{|c|}{ Rubbing $^{\mathrm{z}}$} \\
\hline & & & & $\begin{array}{c}\text { Frequency } \\
{[\text { mean } \pm \text { SE }(\%)]^{\mathrm{u}}}\end{array}$ & $\begin{array}{c}\text { Intensity } \\
{[\text { mean } \pm \mathrm{SE}(\%)]^{\mathrm{t}}}\end{array}$ & $\begin{array}{c}\text { Frequency } \\
{[\text { mean } \pm \mathrm{SE}(\%)]^{\mathrm{s}}}\end{array}$ & $\begin{array}{c}\text { Intensity } \\
{\left[\text { mean } \pm \text { SE }(\%)^{r}\right]}\end{array}$ \\
\hline \multicolumn{8}{|l|}{ Shrubs } \\
\hline American elderberry & $1.75 \pm 0.098$ & $86.74 \pm 6.564$ & $18.0 \pm 1.11$ & $100 \pm 0.033$ & $48.0 \pm 0.043$ & $54.9 \pm 0.053$ & $24.0 \pm 4.704$ \\
\hline American plum & $1.19 \pm 0.098$ & $26.62 \pm 6.564$ & $10.6 \pm 1.11$ & $100 \pm 0.031$ & $45.0 \pm 0.043$ & $10.6 \pm 0.053$ & $24.0 \pm 14.526$ \\
\hline Choke cherry & $1.30 \pm 0.101$ & $17.59 \pm 6.795$ & $10.3 \pm 1.15$ & $94.0 \pm 0.033$ & $53.5 \pm 0.044$ & $28.0 \pm 0.055$ & $44.6 \pm 8.345$ \\
\hline Sand cherry & $0.44 \pm 0.110$ & $13.10 \pm 7.538$ & NA & $97.6 \pm 0.037$ & $51.9 \pm 0.049$ & NA & NA \\
\hline 'Blood-twig' dogwood & $1.15 \pm 0.104$ & $41.72 \pm 7.769$ & NA & $99.9 \pm 0.035$ & $54.6 \pm 0.049$ & $9.8 \pm 0.058$ & $25.0 \pm 7.360$ \\
\hline 'Bailey' redozier dogwood & $1.25 \pm 0.107$ & $50.90 \pm 7.205$ & NA & $99.9 \pm 0.035$ & $50.7 \pm 0.047$ & $2.8 \pm 0.058$ & $5.1 \pm 0.009$ \\
\hline $\begin{array}{l}\text { 'Cardinal' redozier } \\
\text { dogwood }\end{array}$ & $1.55 \pm 0.107$ & $37.74 \pm 7.205$ & NA & $99.9 \pm 0.035$ & $49.0 \pm 0.047$ & $16.3 \pm 0.058$ & $20.0 \pm 6.547$ \\
\hline $\begin{array}{l}\text { 'Colorado' redozier } \\
\text { dogwood }\end{array}$ & $1.09 \pm 0.107$ & $45.03 \pm 7.205$ & NA & $99.9 \pm 0.035$ & $55.0 \pm 0.047$ & $5.3 \pm 0.058$ & $17.5 \pm 7.501$ \\
\hline $\begin{array}{l}\text { 'Yellow-twig' redozier } \\
\text { dogwood }\end{array}$ & $1.08 \pm 0.107$ & $44.33 \pm 7.205$ & NA & $99.9 \pm 0.035$ & $59.2 \pm 0.047$ & $0.3 \pm 0.058$ & NA \\
\hline Forsythia & $0.60 \pm 0.107$ & $25.54 \pm 7.205$ & NA & $97.9 \pm 0.035$ & $35.3 \pm 0.047$ & $0.3 \pm 0.058$ & NA \\
\hline Smooth sumac & $1.46 \pm 0.101$ & $8.23 \pm 6.795$ & $20.3 \pm 1.15$ & $79.9 \pm 0.035$ & $13.8 \pm 0.047$ & $96.0 \pm 0.055$ & $78.1 \pm 4.358$ \\
\hline Pussy willow & $1.88 \pm 0.107$ & $52.77 \pm 7.205$ & NA & $99.9 \pm 0.035$ & $19.6 \pm 0.049$ & $9.3 \pm 0.058$ & $10.0 \pm 2.887$ \\
\hline Curly willow & $2.61 \pm 0.107$ & $45.44 \pm 7.179$ & $22.7 \pm 1.32$ & $92.9 \pm 0.035$ & $10.8 \pm 0.049$ & $83.8 \pm 0.58$ & $45.3 \pm 6.005$ \\
\hline 'Flame' willow & $0.84 \pm 0.107$ & $28.77 \pm 7.205$ & NA & $99.9 \pm 0.035$ & $55.4 \pm 0.047$ & $0.3 \pm 0.058$ & NA \\
\hline 'Scarlet Curls' curly willow & $2.46 \pm 0.104$ & $92.90 \pm 6.949$ & $31.0 \pm 1.22$ & $99.9 \pm 0.033$ & $13.8 \pm 0.047$ & $10.6 \pm 0.056$ & $17.5 \pm 7.274$ \\
\hline 'Streamco' basket willow & $1.11 \pm 0.107$ & $55.82 \pm 7.205$ & NA & $99.9 \pm 0.035$ & $31.8 \pm 0.047$ & $0.3 \pm 0.058$ & NA \\
\hline Winterberry holly & $0.57 \pm 0.101$ & $21.79 \pm 6.795$ & NA & $100 \pm 0.033$ & $44.8 \pm 0.044$ & NA & NA \\
\hline Witch-hazel & $0.45 \pm 0.101$ & $9.08 \pm 6.795$ & NA & $100 \pm 0.033$ & $57.5 \pm 0.047$ & NA & NA \\
\hline \multicolumn{8}{|l|}{ Trees } \\
\hline Black cherry & $1.95 \pm 0.101$ & $104.82 \pm 6.795$ & $23.2 \pm 1.15$ & $100 \pm 0.033$ & $56.7 \pm 0.044$ & $55.5 \pm 0.055$ & $43.2 \pm 6.800$ \\
\hline Butternut & $0.63 \pm 0.101$ & $15.85 \pm 6.795$ & $9.8 \pm 1.15$ & $88.0 \pm 0.033$ & $43.4 \pm 0.044$ & $18.5 \pm 0.055$ & $37.5 \pm 11.573$ \\
\hline Black walnut & $0.77 \pm 0.101$ & $8.31 \pm 6.795$ & $11.1 \pm 1.15$ & $94.0 \pm 0.033$ & $58.3 \pm 0.047$ & $6.0 \pm 0.055$ & $60.0 \pm 28.431$ \\
\hline $\begin{array}{l}\text { 'Peach' chinese } \\
\text { chestnut }\end{array}$ & $1.35 \pm 0.101$ & $26.15 \pm 6.795$ & $12.6 \pm 1.15$ & $100 \pm 0.033$ & $75.9 \pm 0.044$ & $17.7 \pm 0.055$ & $57.8 \pm 11.122$ \\
\hline 'Qing' chinese chestnut & $1.23 \pm 0.101$ & $24.79 \pm 6.795$ & $11.5 \pm 1.15$ & $100 \pm 0.033$ & $71.6 \pm 0.044$ & $20.0 \pm 0.055$ & $61.5 \pm 11.231$ \\
\hline Ginkgo & $0.31 \pm 0.101$ & $4.59 \pm 6.795$ & $5.4 \pm 1.15$ & $40.1 \pm 0.033$ & $12.1 \pm 0.044$ & NA & NA \\
\hline Common persimmon & $1.48 \pm 0.101$ & $81.15 \pm 6.795$ & $17.6 \pm 1.15$ & $94.0 \pm 0.033$ & $43.9 \pm 0.044$ & $24.0 \pm 0.055$ & $34.6 \pm 10.010$ \\
\hline Northern red oak & $0.73 \pm 0.101$ & $13.21 \pm 6.795$ & $7.5 \pm 1.15$ & $96.7 \pm 0.033$ & $53.6 \pm 0.044$ & $11.2 \pm 0.055$ & $50.0 \pm 1.001$ \\
\hline
\end{tabular}

${ }^{2} \mathrm{NA}=$ Plants of some species were too small to be rubbed by male white-tailed deer.

${ }^{\mathrm{l}} \mathrm{l} \mathrm{m}=3.2808 \mathrm{ft}$.

$1 \mathrm{~m}=3.2808 \mathrm{ft}$.
${ }^{1} \mathrm{~cm}=0.3937$ inch.

wNA $=$ Stem diameters were collected only for species of trees and shrubs that had single stems.

$1 \mathrm{~mm}=0.0394$ inch.

"Mean percentage of plants browsed by deer.

Mean percentage of twigs available per plant browsed by deer.

${ }^{r}$ Mean percentage of circumference of plant stems rubbed by male white-tailed deer.
. 
across all species of trees was $49 \%$ and was greatest in chinese chestnut ('Qing' $=62 \%$, 'Peach' $=58 \%$ ), black walnut $(60 \%)$, and northern red oak $(50 \%)$ (Table 2). All other species of trees were rubbed at a frequency $<38 \%$. The mean intensity of rubbing across all species of shrubs was $28 \%$ and was greatest in smooth sumac $(78 \%)$, curly willow (45\%), and choke cherry $(45 \%)$. All other species of shrubs were rubbed at a frequency $<25 \%$. The intensity of stems rubbed was $57 \%$ more in willow species than dogwood species combined. Morphological characteristics of the trees and shrubs contributed little to the explained variance in intensity of rubbing with tree and shrub height, width, and stem diameter explaining $1 \%, 7 \%$, and $1 \%$, respectively.

ECONOMIC IMPACTS OF DEER BROWSING AND RUBBING. Rejection of stems due to browsing by deer ranged from less than $1 \%$ of the total number of stems produced in pussy willow to over $21 \%$ in 'Blood-twig' dogwood (Table 3). Rejection of stems caused by rubbing damage ranged from $0 \%$ in 'Bailey' redozier dogwood, 'Blood-twig' dogwood, 'Flame' willow, and pussy willow to $9 \%$ in curly willow. Losses per year due to combined damage by browsing and rubbing amounted to about $\$ 26 /$ acre for pussy willow, \$2031/acre for 'Blood-twig' dogwood, and \$1595/ acre for curly willow (Table 3 ).

\section{Discussion}

While both fields sustained considerable damage, levels in the north field were higher. The fields were $<0.5$ mile apart and both were easily within the seasonal and annual home ranges of individual deer in the area. Deer may have been attracted to the north field more because the plants there were larger and of higher quality due to better soil and fertility conditions. Because much of the damage from browsing occurred during the fall and winter (noncrop periods), we do not feel that the distribution of crops in the area had much influence on damage levels. Preferred landcover types (wooded plantations and windbreaks) were present near the north field, however, and a waterfilled ditch just north of the south field may have hindered movements of some deer into the south field. Deer have the physical ability to reach

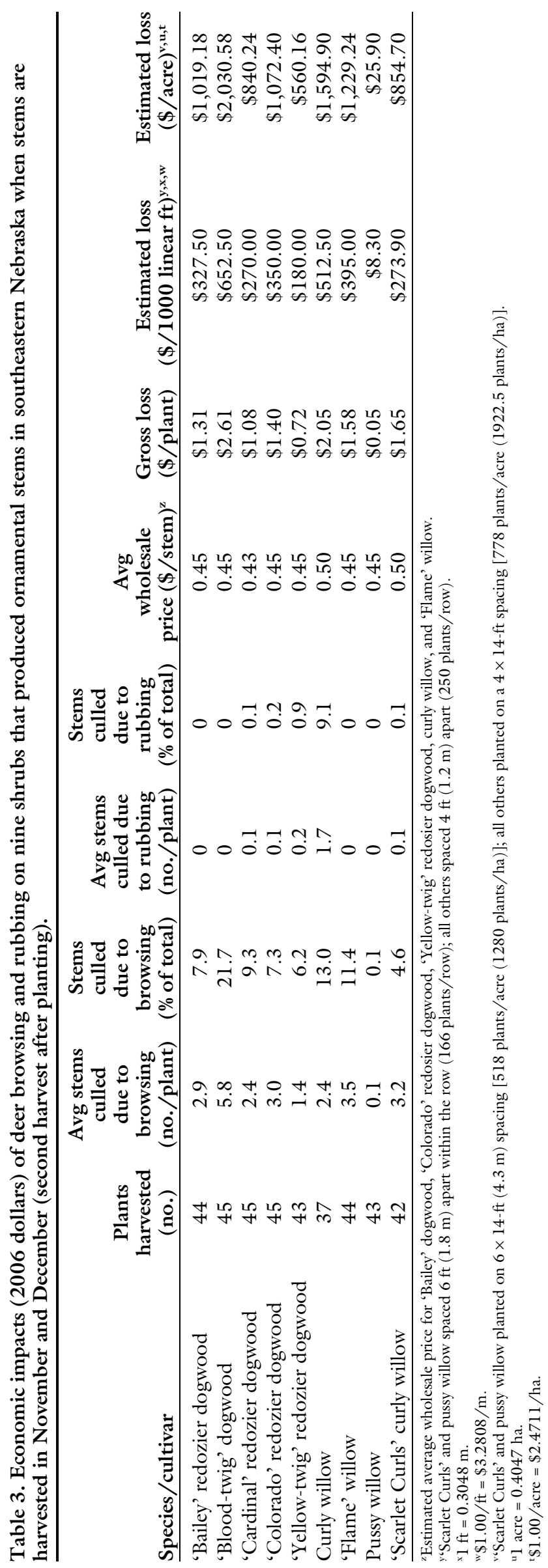


about $6 \mathrm{ft}$ high to browse. Therefore, all twigs on all trees and shrubs were available to deer except for the upper reaches of the tallest black cherry, 'Scarlet Curls' curly willow, and curly willow.

Browsing. The percentage of plants browsed provides a measure of the frequency of deer damage in trees and shrubs. The number of twigs browsed provides a measure of the intensity of damage. We observed high levels of damage by browsing (frequency $>93 \%$ and intensity $>50 \%$ ) in most species of trees and shrubs. Damage levels were highest (intensity $>60 \%$ ) in chinese chestnut and 'Yellow-twig' redozier dogwood and were relatively low (intensity $<20 \%$ ) in ginkgo, curly willow, 'Scarlet Curls' curly willow, smooth sumac, and pussy willow. Selective feeding has been suggested in several studies of deer in natural environments (Conover and Kania, 1988; Hughes and Fahey, 1991; Nixon et al., 1970; Strole and Anderson, 1992). Preferred species vary with geographic area and distribution of vegetation. In Ohio, deer preferred to browse on sumac (Rhus spp.), shrubby dogwood (Cornus spp.), alder (Alnus spp.), and wild sweet crabapple (Malus coronaria) (Nixon et al., 1970). Hughes and Fahey (1991) reported american mountain ash (Sorbus americana) and mountain maple (Acer spicatum) were the most preferred species for browsing in New Hampshire before and after clear-cut harvests of timber. Preferred species in the southern Appalachians included american holly (Ilex opaca), ash (Fraxinus spp.), black cherry, and hazel alder (Alnus serrulata) (Ford et al., 1993). In Illinois, deer preferred choke cherry, gray dogwood (Cornus racemosa), multiflora rose (Rosa multiflora), and white oak (Quercus alba), while avoiding sugar maple (Acer saccharum) and white ash (Fraxinus americana) (Strole and Anderson, 1992).

Deer also showed preference for individual species in tree nurseries and plantations. Conover and Kania (1988) found that deer preferred evergreen more than deciduous species, except for resinous evergreens such as pines (Pinus spp.), spruces (Picea spp.), and firs (Abies spp.). In pine plantations, jack pine (Pinus banksiana) consistently suffered more damage from deer than white pine
(Pinus strobus), red pine (Pinus resinosa), and white spruce (Picea glauca) (Horton, 1964).

Deer in Ohio did not rely heavily on woody browse because they often had access to green forage in nearly all seasons due to snow-free conditions (Nixon et al., 1970). Deer that experienced moderate to severe winters relied on woody browse only when forced by deep snow cover (McCaffery et al., 1974; Rose and Harder, 1985). Analysis of rumen contents confirmed that deer fed on grasses, sedges (Cyperaceae spp.), and dead leaves in the winter months when snow was not excessive (McCaffery et al., 1974; Rose and Harder, 1985 ). Browse was a major component in diets of deer in areas that were heavily vegetated with woody species in southern Texas and northern Mexico (Koerth and Stuth, 1991).

Selection of foods may be due to an animal's ability to assess the nutritional quality of different plant species. In a controlled study of four experimental foods with known energy and protein levels, deer selected diets high in energy and low in protein, which was consistent with the physiological needs of deer during winter (Berteaux et al., 1998). Similarly, deer in Texas appeared to selectively feed more and for longer periods of time on preferred species of browse and attempted to obtain nutrient-optimizing diets within a fixed amount of food (Koerth and Stuth, 1991).

Rubbing. The frequency and intensity of rubbing by deer was considerably less than browsing. We observed moderate levels of damage by rubbing (mean frequency was $17 \%$ and intensity was $49 \%$ and $28 \%$ in trees and shrubs, respectively). Damage levels were relatively high $(>55 \%)$, however, in black cherry, smooth sumac, curly willow, and american elderberry. The growth form of the latter three shrubs was tree-like and as a result, the frequency of rubbing was higher than all other shrubs $(<10 \%)$. The growth form of several shrubs and trees [sand cherry, winterberry holly (Ilex verticillata), witch-hazel, and ginkgo] was too small for deer to rub $(<0.6 \mathrm{~m}$ high and $<6 \mathrm{~mm}$ stem diameter $)$.

Male white-tailed deer appear to select certain species of trees for rubbing. Species of trees rubbed by bucks often are aromatic [e.g., Prunus spp. (e.g., cherry, plum), Juniperus spp. (e.g., juniper)] with no lower branches $(<0.5 \mathrm{~m})$ and smooth bark (Kyle and Marchinton, 1977, Nielsen et al., 1982). Miller et al. (1987) reported that the percentage of rubbing exceeded availability in alder, cherry, juniper, virginia pine (Pinus virginiana), white pine, witch-hazel, and striped maple (Acer pennsylvanicum), suggesting preference for these species. Deer preferred to rub green ash, plum, cherry, red maple (Acer rubrum), linden (Tilia spp.), and other small trees (16-25 mm diameter, $15 \mathrm{~cm}$ aboveground) in a nursery in Ohio (Nielsen et al., 1982). Deer avoided larger diameter trees and trees with warty bark such as sweet gum (Liquidambar styraciflua) and trees with spines such as hawthorns (Crataegus spp.) (Nielsen et al., 1982). The majority of rubs in our study $(>78 \%$ ) occurred on trees $<27$ $\mathrm{mm}$ in diameter at the midpoint of the rub. Litchfield (1987) reported that hazel alder, eastern red cedar, loblolly pine (Pinus taeda), and sumac were preferred for rubbing by deer in Georgia, and the mean diameter of rubbed trees was $24 \mathrm{~mm}$.

ECONOMIC IMPACTS OF DEER BROWSING AND RUBBING. The financial impacts of deer browsing and rubbing on nontimber forest products in general, and woody ornamental plantings in particular, can be considerable, as heavily browsed tips or rubbed stems are not marketable, and thus are a direct loss to the owner. Losses of trees and shrubs due to deer damage can amount to over \$2030/ acre per year, depending on the species. However, annual gross income can approach $\$ 698 /$ acre for 'Bloodtwig' dogwood, $\$ 9999 /$ acre for pussy willow, and $\$ 13,694 /$ acre for 'Scarlet Curls' curly willow.

Managing DeER DAMAge IN NONTIMBER FOREST PRODUCT PLANTINGS. Our experience in Mar. 2001 indicated that leaving nontimber forest products in the field until late winter considerably increased the percentage of stems of particular species or cultivars (especially dogwoods) rendered unmarketable due to damage by browsing. In an effort to reduce damage by deer, we harvested all dogwoods in late November or early Dec. 2001 and again in 2002. While we did not collect data on damage by browsing in later years, we observed that harvesting in late fall 
and early winter substantially reduced the percentage of stems with browse damage by deer.

In addition to modifying the environment, several other approaches should be considered to abate damage caused by deer, including fencing and other forms of exclusion, repellents, frightening devices, and population reduction through hunting, sharpshooting, trapping and removal, and fertility control where appropriate (Craven and Hygnstrom, 1994).

\section{Literature cited}

Berteaux, D., M. Crête, J. Huot, J. Maltais, and J.P. Ouellet. 1998. Food choice by white-tailed deer in relation to protein and energy content of the diet: A field experiment. Oecologia 115:84-92.

Chamberlain, J. 2001. Managing national forests for non-timber forest products. Virginia Polytechnic Institute and State University, Blacksburg, Ph.D. Diss.

Conover, M.R. 1984. Effectiveness of repellents in reducing deer damage in nurseries. Wildl. Soc. Bul. 12:399-404.

Conover, M.R. 1987. Comparison of two repellents for reducing deer damage to japanese yews during winter. Wildl. Soc. Bul. 15:265-268.

Conover, M.R. and G.S. Kania. 1988. Browsing preference of white-tailed deer for different ornamental species. Wildl. Soc. Bul. 16:175-179.

Craven, S.R. and S.E. Hygnstrom. 1994. Deer, p. D25-D40. In S.E. Hygnstrom, R.M. Timm, and G.E. Larson (eds.). Prevention and control of wildlife damage. Univ. Nebraska Coop. Ext, Lincoln.

Ford, W.M., A.S. Johnson, and P.E. Hale. 1993. Yellow-poplar flowers in the spring diet of white-tailed deer in the southern Appalachians. J. Tenn. Acad. Sci. 68:56.

Horton, K.W. 1964. Deer prefer jack pine. J. For. 62:497-499.

Hughes, J.W. and T.J. Fahey. 1991. Colonization dynamics of herbs and shrubs in a disturbed northern hardwood forest. J. Ecol. 79:605-616.
Jones, J.M. and J.H. Witham. 1995. Urban deer "problem" solving in northeast Illinois: An overview, p. 58-65. In J.B. McAnnich (ed.). Proc. 55th Midwest Fish Wildlife Conf., St. Louis.

Josiah, S.J., H. Brott, and J. Brandle. 2004a. Producing woody floral products in an alley cropping system in Nebraska. HortTechology 14:203-207.

Josiah, S.J., R. St. Pierre, H. Brott, and J. Brandle. 2004b. Productive conservation: Diversifying farm enterprises by producing specialty woody products in agroforestry systems. J. Sustain. Agr. 23:93-108.

Kyle, K.L. and R.L. Marchinton. 1977. White-tailed deer rubs and scrapes: Spatial, temporal, and physical characteristics and social role. Am. Midl. Nat. 97:257-266.

Kilpatrick, H.J., S.M. Spohr, and G.C. Chasko. 1997. A controlled deer hunt on a state-owned coastal reserve in Connecticut: Controversies, strategies, and results. Wildl. Soc. Bul. 25:451-456.

Koerth, B.H. and J.W. Stuth. 1991. Instantaneous intake rates of nine browse species by white tailed deer. J. Range Mgt. 44:614-618.

Kuser, J. 1995. Deer and people in Princeton, New Jersey, 1971-1993, p. 47-50. In J.B. McAninch (ed.). Proc. 55th Midwest Fish Wildlife Conf., St. Louis.

Lambe, D. 2001. Woody decorative floral market near-national assessment. University of Nebraska, Lincoln.

Litchfield, T.R. 1987. Relationships among white-tailed deer rubbing, scapping, and breeding activities. University of Georgia, Athens, Thesis.

Mater, C. 1996. Consumer trends, market opportunities, and new approaches to sustainable development of specialty forest products, p. 8-25. In N.C. Vance and J. Thomas (eds.). U.S. Dept. Agr. For. Serv. Gen. Tech. Rpt. GTR-WO-63.

Mayer, K.E., J.E. DiDonato, and D.R. McCullough. 1995. California urban deer management: Two case studies, p. 51-57. In J.B. McAnnich (ed.). Proc. 55th Midwest Fish Wildlife Conf., St. Louis.

McCaffery, K.R., J. Tranetzke, and J. Piechura. 1974. Summer foods of deer in northern Wisconsin. J. Wildl. Mgt. 38:215-219.

Miller, B.K., B.C. Moser, K.D. Johnson, and R.K. Swihart. 1994. Designs for windbreaks and vegetative filterstrips that increase wildlife habitat and provide income, p. 567-574. In K.L. Campbell, W.D. Graham, and A.B. Bottcher (eds.). Proc. 2nd Conf. Environmentally Sound Agriculture. Amer. Soc. Agr. Eng., Orlando, FL.

Miller, K.V., K.E. Kammermeyer, R.L. Marchinton, and E.B. Moser. 1987. Population and habitat influences on antler rubbing by white-tailed deer. J. Wildl. Mgt. 51:62-66.

Nielsen, D.G., M.J. Dunlap, and K.V. Miller. 1982. Pre-rut rubbing by whitetailed bucks: Nursery damage, social role, and management options. Wildl. Soc. Bul. 10:341-348

Nixon, C.M., M.W. McClain, and K.R. Russell. 1970. Deer food habits and range characteristics in Ohio. J. Wildl. Mgt. 34:870-886.

Robles-Diaz-de-Leon, L.F. and P. Kangas. 1997. Evaluation of economic gains from non-timber products in a riparian forest in the Chesapeake Bay watershed, p. 82-86. Fifth North Amer. Conf. Agroforestry, Cornell, NY. (Abstr.).

Rose, J. and J.D. Harder. 1985. Seasonal feeding habits of an enclosed high-density white-tailed deer herd in northern Ohio. Ohio J. Sci. 85:184-190.

Solutions 2000+ Management Consultants. 1994. Solutions Specialty berry market assessment study. Saskatchewan Indian Agr. Prog. Inc. and Saskatchewan Dept. Agr. Food, Regina, Saskatchewan, Canada.

Strole, T.A. and R.C. Anderson. 1992. White-tailed deer browsing: Species preferences and implications for Illinois forests. Nat. Areas J. 12:139-144.

U.S. Bureau of the Census. 1993. U.S. government population studies. U.S. Government Printing Office, Washington, DC.

Weeder-Einspahr, S. 2001. Midwest wild fruits and berries: Market research report. Food Processing Ctr., University of Nebraska, Lincoln. 